\title{
Using Barbaric Methods in South Africa: The British Concentration Camp Policy during the Anglo-Boer War
}

\author{
James Robbins Jewell ${ }^{\bullet}$
}

\begin{abstract}
The Boer War, which is frequently referred to as Britain's Vietnam or Afghanistan, was marked by gross miscalculations on the part of both British military and political leaders. In their efforts to subdue the Boers, Britain used more troops, spent more money, and buried more soldiers than anytime between the Napoleonic wars and World War I - a century during which it had been busy expanding its empire. Despite the miscalculations, lapses in judgement, and blatant stupidity demonstrated throughout the war by the British leaders, historically speaking, one policy remains far more notorious than any other. Unable to bring the war to a conclusion through traditional fighting, the British military, and in particular the two men who were in command, Frederick, Baron Roberts and Herbert, Baron Kitchener, responded to the Boer use of guerilla warfare by instituting a scorched earth combined with a concentration camp policy. ${ }^{1}$ Nearly forty years later, Lord Kitchener's decision to institute a full-scale concentration camp strategy came back to haunt the British. On the eve of the Second World War, when a British ambassador to Germany protested Nazi camps, Herman Goering rebuffed the criticism by pulling out an encyclopedia and looking up the entry for concentration camps, which credited the British with being the first to use them in the Boer War. ${ }^{2}$ Under the scrutiny that comes with the passage of time, the concentration camp policy has rightfully been viewed as not only inhumane, but hopelessly flawed. When Lords Roberts and Kitchener, who were desperate to counter the Boers' effective use of guerilla warfare, turned to the concentration camp policy they failed to consider that the plan might fail. In the end the strategy, in a number of ways, actually benefited
\end{abstract}

\footnotetext{
- Visiting Professor, Bloomsburg University and Ph.D. Candidate West Virginia University. The author would like to acknowledge the valuable suggestions and insights offered by Dr Steve Zdatny, Lt Col Ian van der Waag, and the anonymous reviewers.

1 Of course the British employment of a scorched earth policy was hardly the first use of such a strategy. In 1812 the Russians used it effectively as a defensive measure against Napoleon's invading armies to prohibit the French from obtaining food and supplies from the conquered lands. In 1864 during the American Civil War, Union generals William Sherman and Philip Sheridan both burned swaths through Confederate territory to both deprive the enemy of supplies and to break their will to fight on. Chronologically closer to the Anglo-Boer war was Cuban General Maximo Gomez's orders to destroy the sugar cane plantations in an effort to break the backbone of the aristocrats who were as much a target of the Cuban revolution as was the Spanish government. Later, during the Second World War, the Soviets followed the lessons of 1812, this time against the invading Germans.

2 Rayne Kruger, Good-bye Dolly Gray: The Story of the Boer War. (Philadelphia and New York: J.B. Lippincott Company, 1960), 372.
} 
the Boers militarily while simultaneously proving to be a public relations disaster for the British government. $^{3}$

So what was it that led the British leaders to institute a concentration camp policy and why was it such an overwhelming disappointment (both militarily and sociopolitically)? To answer these questions it must be realized that the fighting of the war went through three distinct phases, the last of these being guerilla warfare - for which the British found themselves ill prepared. As part of the counter measures employed to combat the guerilla war waged by the Boers, Kitchener turned to the idea of concentration camps. He also employed the use of blockhouses to protect his supply lines and the creation of specialized, and highly mobile, mounted forces, among other strategies. The plan was to gather the families of commandos still in the field in one of nearly fifty (frequently overcrowded) camps where they lived in either tents or reed huts. While there they were provided with either full or half rations of the same fare that the British troops in the field received, and provided with little or no clothing or medical treatment. Militarily, the policy actually benefited the Boer commandos while simultaneously proving to be a public relations disaster for the British government. That the British would even be in a war long enough to necessitate altering its basic strategy was inconceivable in early October 1899 as the likelihood of war rapidly increased.

On 9 October 1899 representatives of the British government in Pretoria, South Africa, received an ultimatum from Boer officials. ${ }^{4}$ Transvaal President Paul Kruger defiantly demanded that all recently arrived British troops, as well as those on their way to South Africa should withdraw or turn back and that the government in London should agree to arbitration of the disputes between the Republics and Britain. Although the British government made references to the disenfranchisement of the Uitlanders (foreigners), a large percentage of whom were Englishmen, the truth was that the dispute had almost nothing to do with enfranchising anyone. The real issue was that the British coveted the gold and diamond rich, sparsely populated lands of the Transvaal and the Orange Free State. ${ }^{5}$ Furthermore, the British were determined that the Transvaal would not become the dominant economic force in South Africa. Thus, two days later, after the Boer ultimatum passed, war broke out between industrialized England and the rugged, agrarian Boers.

As with their other colonial experiences in Africa, the British confidently assumed that their military might, presumed superior technology, and numerical superiority would easily enable them to defeat whatever resistance the Boers might muster. This was just the first in a string of miscalculations by the British military leaders that eventually

3 Donal Lowry noted in a recent History Today article that "the tactics of farm burning an concentration camps employed by the British added further charges of brutality and moral corruption before the bar of public opinion." Donal Lowry, "When the World Loved the Boers," History Today 49 (1999) 5, 43.

4 L.S. Amery, Times History of the War in South Africa, 1899-1902, seven volumes. (London: S. Low, Marston, and Company, 1900-1909), 1: 372-372.

5 This position is denied, unconvincingly, in the London Times multi volume history of the war. Well aware of the criticism of the governments" actions, the editor stated, "It has sometimes been asserted that the British Government gratuitously provoked war over a petty detail of the franchise scheme ... and then made war an excuse for annexing territory which it had long been coveting. Nothing can be farther from the truth." Amery, Times History of the War, 1: 376. 
resulted in the South African (or Boer) War being the costliest conflict in the one hundred years between the end of the Napoleonic Wars and the First World War. One of the most important British miscalculations was that their enemy, who were better suited at fighting running skirmishes than pitched battles, did not adhere to traditional means of waging war. This being the case, it was no surprise then on 24 September 1900 when the last of the major Boer cities fell, that the British high command assumed the war was over. So convinced were the British that Lord Roberts, commanding officer of the forces in South Africa, departed for England in early December and turned over the responsibility of defeating the few remaining bands of disorganized Boers to Lord Kitchener.

What the British failed to comprehend, and what Lord Kitchener was left to address, was that, despite conventional military logic, the war was far from over. Only the nature of the war had changed. With their older, more traditional commanders held prisoner, deceased, or exiled like Kruger, young, vigorous, and skilled Boer leaders led still defiant commandos in carrying out a guerilla war. ${ }^{6}$ In response, Kitchener and his subordinates formulated the best possible plan to defeat an enemy who was highly mobile, had no appreciable central supply base to be destroyed, who hit small contingents of British troops hard, and then disappeared into the expanse of the veld before a pursuit could be mustered. Kitchener's response was to strike at the Boers' support, their farms and their families. Kitchener was convinced that the commandos' families were their chief source of supplies and therefore the best means to diminish their ability to continue fighting was to remove that source. According to this strategy, the British burned Boer farms, killed or confiscated their livestock, and eventually forced the civilians into camps with other displaced Boer families. This led to the formal creation of a concentration camp policy. Close examination of what led the British high command to institute such a strategy, as well as both the military and socio-political outcome, make it clear that the concentration camp policy was the major blunder in a war marked by poor British decisions.

From the outset the British military failed to grasp the nature of a war they had all too happily gotten themselves into. ${ }^{7}$ The first misconception was that the Boers could be easily subdued. This, however, failed to take into account the nature of the Boers' commitment to fighting on. They were well aware that they were fighting for their independence. It was this motivation that led the Boers to continue the war well after the British believed they were victorious. The British failure to accurately assess how formidable a task it would be to subdue the Boers is baffling. The British, after all, had maintained a volatile relationship with the Boer people since they acquired control over Boer territories along coastal southern Africa during the Napoleonic Wars. The fragile nature of that relationship had finally erupted into open conflict in 1880-81. In the face of logical military dictums, the Boers were not intimidated by the spectre of the industrial

${ }^{6} \quad$ At the outset, Kitchener was just as ill prepared as Roberts. As Major General E.K.G. Sixsmith noted, "Kitchener had to learn . . . that you cannot make war against a map." Major General E.K.G. Sixsmith, "Kitchener and the Guerillas in the Boer War," The Army and Defence Journal, 104 (1974) 2, 207.

7 MP A.J. Balfour, who became Prime Minister in 1902, believed that the war had been so mismanaged at the outset so as to warrant a governmental inquiry. Denis Judd, Balfour and the British Empire. (London, Melbourne, and Toronto: Macmillan, 1968), 184. 
and military might of Great Britain. Their confidence appeared well founded as they proceeded to inflict a stinging defeat on the British in the brief First Anglo-Boer War.

This victory over the mighty British had two important results. The first one was immediately apparent whereas the other the importance of the other was not apparent for years to come. Partly as a result of pre-war plans and partly as a result of Boer determination to maintain their independence, the British government granted the Transvaal qualified autonomy. Although it was not everything the Boer people wanted, it was certainly better than the previous arrangement, under which the Boers were ruled as a crown colony with little say in their own affairs. What was important in 1899 was the loss of the British Empire's aura of invincibility. The Boers, who had not believed in the supremacy of the British Empire even before their victory, regarded the British with exponentially more contempt after the First Anglo-Boer War. As historian Byron Farwell noted, the Boers defeated the British in every battle of the three month long war "acquiring in the process a somewhat exaggerated concept of their own powers, considerable though they were, and a hearty contempt for the British army. This is not surprising, for the undeniable fact is that a group of South African farmers did indeed humble the proud and might British army." " Boer confidence was matched by British apathy toward the Boers; it had only been a three-month affair after all, and it was the politicians who were eager to discontinue a struggle that offered only limited rewards. Certainly, the military would have crushed the Boers had it only been given a real opportunity.

The reality was that many of the British leaders in power in 1899 , both political and military, failed to heed the historical lessons learned in 1880-81 (and reaffirmed in 1895 when a small force of British citizens living in Rhodesia, led by Dr. Leander Starr Jameson, attempted to capture Johannesburg, but were resoundingly defeated in the attempt). Ever since they took control of Boer territories during the Napoleonic Wars, British officials had looked upon the populace with derision. This arrogance and lack of respect for the determination and fighting ability of the Boer burghers was an important factor in the British defeat during their first conflict. Almost twenty years later, too many Englishmen still believed, as Lord Kitchener did, that the Boers "are uncivilized Africander savages with a thin white veneer" who are "a type of savage produced by generations of wild lonely life." That Kitchener was one of the many who subscribed to this dehumanized view of the Boers had important consequences, for it was he who ordered the destruction of Boer farms and the interment of civilians.

The widespread marginalization of not only the Boer state of civilization, but also their ability to stand up to the British army was a direct contributor to the string of defeats the British suffered in the first months of the war. As the young Winston Churchill noted a month after the war started, British setbacks were "due to an extraordinary underestimation of the strength of the Boers." He went on to note, "the enduring courage and confident spirit of the enemy must also excite surprise. In short, we have grossly

8

Byron Farwell, Queen Victoria's Little Wars. (New York, San Francisco, and London: Harper and Row, 1972), 242. Farwell gives a concise history of the brief First Anglo-Boer War in this text, 141-152, passim.

9 Quoting Kitchener in Magnus, Kitchener: Portrait of an Imperialist. (New York: Dutton, 1959), 185. 
underrated their fighting powers. Most people in England - I among them - thought that the Boer ultimatum was an act of despair, that the Dutch would make one fight for their honour, and, once defeated, would accept the inevitable," but they were wrong in dismissing the Boers so easily. ${ }^{10}$ Churchill had no idea just how correct his prophecy would be.

The military aspects of the Boer War are analogous to a three-act play, in which the first two acts set the stage for the high drama of the final act. In terms of setting up the third it is not especially important that the Boers dominated the first act and the British second. What is significant is that throughout the first two phases of the war the Boers fought in a pseudo-traditional military style, which only reinforced British misconceptions about the nature of the war. By the conclusion of second phase of the war in early fall 1900, all the major Boer cities were under British control and most of its political leaders had fled, the British military commanders were utterly confused when the Boer commandos did not stop fighting. It was during the last phase of the war, from early 1901 through the end of the war on 31 May 1902 that proved to be the deadliest. Thus to understand what led the British to come up with such a devastating counter guerilla warfare strategy it is important to consider the progression of the war to that point.

Between the outset of the war in October and the first week of February 1900 the Boers demonstrated not only the courage and spirit Churchill alluded to, but also military skill. The result was a string of Boer victories at such places as Belmont, Graspan, Modder River, and Magersfontein. In each instance outnumbered Boers used their mobility (a result of their expert horsemanship) and expertise with both small arms and their few pieces of artillery to defeat a foe which attacked as if it was marching up Breed's Hill in 1775. One correspondent in the besieged city of Ladysmith remarked of the Boers' surprising skills in a November 1899 letter to American novelist Stephen Crane, "We are intermittently bombarded ever day by the Boers who have better guns \& I think better gunners than we have." British battle casualties tallied in the thousands for these first few months of the war - an unexpected sum that was far higher than they had suffered anytime since the Battle of Waterloo. ${ }^{12}$ Although Boer success surprised the British, they had, up to that point, fought in a way more or less reminiscent of the traditional fighting, carried out by massed forces confronting each other on a relatively small field of battle, just as the officers had studied at Sandhurst. This being the case, British commanders were confident that once a sufficient force arrived they would defeat the Boers with relative ease.

If the British were to halt the tide of defeat, changes had to be made. On 10 January 1900 the most important of those changes occurred when Lord Roberts arrived to

10 Winston Churchill, The Boer War. (New York: Dorset Press, 1991), 32. This is a reprint work that combines Churchill's two separate volumes on the war (London to Ladysmith and Ian Hamilton's March) into one book.

11 Stanely Wertheim and Paul Sorrentino, editors, The Correspondence of Stephen Crane, two volumes. (New York: Columbia University Press, 1988), 2:549.

12 Unlike the first Anglo-Boer War, the British government had no intention of giving up the effort for the simple reason that, unlike in 1881, there was something worth fighting for in the Transvaal - gold had been discovered there in 1886 . 
take command of the British forces in South Africa. Roberts was called to South Africa based on his forty-one years of successful service throughout the Empire, during which he had won laurels in the Afghan campaign and in India. ${ }^{13}$ For over one hundred thousand Boer civilians it was equally important that Roberts' second in command, Lord Kitchener, arrived with his commander. First Roberts, and then Kitchener, dictated the nature of the war for its final two years.

Roberts' arrival invigorated the British troops, who began to win battles shortly after he assumed command. The first British victory came on 15 February when a relief force broke through the Boer siege-lines and liberated the city of Kimberly. In the following month, British forces captured not only a large Boer force, along with highly skilled General Cronje, but then, on 13 March, Roberts led his forces into Bloemfontein the capital city of Orange Free State. ${ }^{14}$ As far as the British were aware, all was going according to plan - once reinforcements arrived and Roberts had taken over, the Boers were swept before him. What Roberts and other British commanders failed to notice was the manner in which they captured Bloemfontein. After putting up some initial resistance early on in the move toward the city, the Boer forces simply abandoned it. The British army marched into the city unopposed. This nuance was lost on the British high command. In effect, the British military failed to respond to lessons that should have been learned in the seventeen hundreds in North America fighting first the French, and later the American colonists, as well as in Africa throughout the colonial period. Knowing they could not stop a large British force by becoming entangled in a drawn-out battle while being hampered by having to protect a city, Boer leaders abandoned the city in order to fight under better circumstances. This decision was the first step toward the guerilla war that followed. $^{15}$

Although Roberts continued to win victories the war was changing. The Boers moved increasingly away from fighting traditional battles with their enemy and were less and less inclined to defend their towns and cities. For his part, Lord Roberts never understood how to deal with the roving bands of Boers that harassed his communication lines. The British commander's response was to press on and capture more towns and territory. Next Roberts captured Johannesburg, which fell on 31 May. Given his commitment to capturing land and the few Boer cities, Roberts' believed 5 June, when he led some 25,000 troops into Pretoria, the capital of the Transvaal, was an important event in the winning of the war. Having captured both capital cities, he believed the war was certainly near its end. With few targets left, the British commander focussed his efforts on capturing the towns along the Mozambique Railroad, which he believed were key components for supplying the Boers. The last of these, Komatipoort, fell on 24 September. After capturing all the important cities and towns and believing the war was

\footnotetext{
13 Amery, Times History of the War, 3: 331-332.

14 Bloemfontein was the capital of the Orange Free State, one of the two Boer republics at war with the Britain.

15 The failure of Roberts' strategy to end the war is addressed in Rob McClary, Learning the Hard Way, or not at All: British Tactical and Strategic Adaptation During the Boer War 1899-1902. (Fort Leavenworth, Kansas: United States Army Command and General Staff College, 1999), 2025 .
} 
all but over, Roberts announced the annexation of the Transvaal on 24 October and prepared to return to England, which he did in December.

Despite his public comments, Roberts was not entirely unaware of the situation he left Kitchener as he departed for a hero's welcome in England. There had been a transition period between the second and third phase of the war. Roberts, although convinced that victory could only be achieved by capturing Boer cities and territory, did acknowledge that something would have to be done about the few "bitter-enders" who roamed the veldt. Not all British officials shared Roberts' confidence that this was just a mere mopping up operation. Alfred, Viscount Milner, the High Commissioner of South Africa, demonstrated both a bit of sound military analysis and, at the same time, British racism toward the Boers, when he wrote:

And our victory is far from complete. Of course, we have absolutely smashed up the armies of the enemy and his political organization. A more highly organized and advanced political entity would be annihilated by the loss of its capital, treasury, archives, and the whole machinery of Government. But, with their primitive social and political conditions, the Boers can go on merrily for a long time without any of these. ${ }^{16}$

What Milner could see that Roberts either did not understand, or simply chose to ignore, was that there were still thousands of Boer commandos in the field. Without any cities to defend, those commandos could initiate a style of warfare more suited for their abilities. These bands, Milner noted, "with nothing to defend and nothing to lose, are actually more harassing ... than the genuine armies of Joubert and Cronje." 17 To defeat such a foe was the task left to Kitchener and in order to do so he had to drastically alter the British strategy.

Roberts had, in fact, begun to deal with the bands of Boer commandos by employing counter measures, but the strategy was only in its early stages when Kitchener took over. Between the two of them they came up with a two-fold response to stopping the Boer commandos. First, the blockhouse system that was designed to infringe upon the Boer's ability to use the vastness of the landscape to their advantage was established. Secondly, they organized British forces especially suited for pursing and fighting a wellmounted and widely dispersed enemy. The military leaders believed the most appropriate troops for such a task were not Englishmen at all, but rather colonials from Australia. Beginning in December 1899 recruiters began organizing special "bushmen" units (among the most famous, or perhaps notorious, of the anti-commandos was Lieutenant Harry H. Morant, or "The Breaker," as he has come to be called, of the Bush Veldt Carbineers). ${ }^{18}$ Volunteers had to not only be physically fit, they were also required to

\footnotetext{
16 Cecil Headlam, editor, The Milner Papers, two volumes. (London, Toronto, and Melbourne: Cassell and Company, 1933), 2: 205-206.

17 Ibid.

18 The trial and execution of Lieutenants Morant and Peter Handcock has been the basis of a novel, play, and a motion picture. For a defense of those accused of shooting Boer prisoners (and a missionary) see George Witton, Scapegoats of the Empire: The True Story of Breaker Morant's Bushveldt Carbineers. (London: Angus and Robertson Publishers, 1983 edition of 1907 printing).
} 
demonstrate that they were both excellent horsemen and marksmen. ${ }^{19}$ Secondly, and certainly the most controversial decision of any made during the war, was the policy of destroying the homes of anyone suspected of assisting the Boer commandos, and out of this in turn grew the concentration camp plan.

While the use of irregular troops to combat the Boers was partially effective, the concept of interning the commandos' families proved a fiasco. The idea of putting Boer families in camps as a military strategy first came about in late 1900. By that time Kitchener had grown frustrated with his inability to capture or destroy the free riding commando forces that operated independently throughout the open spaces of the two Boer republics. At that time he reasoned that the best way to hinder the Boer commandos' abilities to continue fighting was to remove or destroy anything that might provide them with sustenance or assistance. This meant the systematic burning of any farm that belonged to a burgher serving in any of the commando units and the interning of his family. According to Roberts and Kitchener, internment, itself, was instituted for two reasons, the first being the need to protect the families of those burghers who had signed oaths of allegiance to the British, and secondly (and more important to Kitchener), to deprive the commandos of any support their families might provide.

This same logic led the British military to intern black African families as well. It was not so much that they might actively assist the Boers, but that the Boers might raid their homes and take needed supplies. The treatment of the civilians in the black concentration camps is beyond the scope of this article, but it is important to recognize that there are parallels between the Boer and indigenous experience. Populations in both camps rapidly increased from mid 1901 through the end of the war. ${ }^{20}$ The inhabitants, albeit for different reasons, were largely children and women. Finally, just as in the Boer concentration camps, thousands died in the black concentration camps due to overcrowding, poor medical treatment, and insufficient shelter and food supplies. ${ }^{21}$

Although it took Kitchener far too long to realize it, this new strategy was no more effective militarily than what had already been done. It was not a lack of attention to the task that resulted in the policy being a failure; for example one British soldier recalled, "marching about the country [and] carrying on the work of destruction pretty indiscriminately, and we have burnt and destroyed by now many scores of farms. Ruin, with great hardship and want, which may ultimately border on starvation may be the

19 Laurie Field, The Forgotten War: Australia and the Boer War. (Melbourne: Melbourne University Press, 1995), 132 and 133.

In sizing up the different attitudes between the use of the scorched earth/camp system against the Boers and the native Africans, Professor Bill Nasson writes, "The Liberal moral revulsion over the Boer camp system and Britain's perceived perversion of the rules of civilized warfare forms the most single-minded political issue of the war, and of the establishment of black concentration camps . . creating no contemporary fuss." Bill Nasson, The South African War 1899-1902. (London, Sydney, Auckland: Arnold, 1999 ) 222.

21 For a brief overview of this understudied aspect of the Boer War see, B.E. Mangalo and Kobus du Pisani, "Victims of a white man's war: Blacks in concentration camps during the South African War (1899-1902)," Historia, 44, (May 1999) 1: 148-182. A detailed account can be found in P. Warwick's Black people and the South African War 1899-1902 (Johannesburg: Ravan Press, 1983). 
result to many families." 22 Others were even upbeat about the new direction the war had taken. Some, like Jack Wynn, reveled in the task:

We did some good as we captured a good many prisoners and burnt every farm and all forage and mealies we could not use ourselves .... I go into all the rooms and turn everything upside down, cut the mattresses of the beds open to look for rifles .... If I am sent to a farm to see what is in it and to get the women out I never hesitate to burn the place before I leave, and only give the people five minutes to pack up and get into the wagon. I have no pity on them no matter how they weep. ${ }^{23}$

In actuality, the British troops were too proficient at this work. Eventually, when it was time to place the women and children in camps, the military showed how ill prepared it was for such an influx of homeless, needy civilians. Leaving the Boer civilians alone and destitute on the veldt, although militarily the most expedient response, was deemed too inhumane, and therefore was never a long term option. This being the case, it fell to Kitchener to devise a plan to provide for these families, which rapidly increased into the thousands and then tens of thousands and finally over one hundred thousand by 1902 . Kitchener, of course, was a solider who was busy devising the best means possible to kill or capture the male relatives of the internees, and thus his interest in creating camps was limited. Compounding the problem was that British political officials in South Africa, such as Milner, proved even more unprepared to address the monumental task. ${ }^{24}$

Interning the Boer civilians did not necessitate the diverting of a significant number of troops, so in that sense the cost was relatively minimal, but the investment of troops to round up the families, destroy the farms, and confiscate/kill the livestock across such a vast spread of land was heavy. In terms of allocation of manpower Kitchener soon found that he had created more trouble for himself than for the commandos. Kitchener's military interest in continuing the concentration camp idea was based on the belief that doing so would inhibit the Boer commandos' fighting abilities. The belief was that without their families and farms to resupply them, compounded by the anxiety the Boers would feel over the uprooting of their relatives, both their ability to continuing fighting and will to do so would dissolve. Although the Boer commandos certainly felt anxiety over the loss of their farms and forced interment of their families, the British strategy was based on yet another misunderstanding of their enemy.

Kitchener was correct that the clearing of the veldt of Boer farms and their inhabitants would hurt the commandos, but it did not occur as he expected. Kitchener believed that the commandos relied heavily on their farms and those of sympathizers for supplies and intelligence. He was partially correct on the latter point, but only marginally so on the first. The fact was that by the last stage of the war the Boers acquired most of their arms, and a portion of their clothes, from the British through one fashion or

\footnotetext{
22 L. March Phillipps quoted in Tabitha Jackson, Boer War. (London: Channel 4 Books, 1999), 130.

23 Jack Wynn quoted in Jackson, Boer War, 133.

24 Thomas Packenham, The Boer War, (New York: Random House, 1979), 524 and 549.
} 
another. $^{25}$ Although reliance on their enemy for food was less regular, foodstuffs captured from British supply trains supplemented the lean diet the commandos maintained. As for maintaining the supply of munitions and arms, armed burgher Deneys Reitz provided a telling overview when he wrote how he and his comrades made up for shortages: "We were getting short of ammunition, so during the next two days we followed the road by which the English force had traveled, to pick up Lee-Metford cartridges. The English soldiers were notoriously careless with their ammunition .... So much was this the case that latterly it had become a regular practice to trail the columns. . . to glean these crumbs from the rich man's table." 26 Reitz and his friends were hardly alone in turning to the British for supplies. While on commando, Dietlof van Warmelo remembered how "the khakis [British] very kindly made over some of their provisions, arms, and ammunition to us in a skirmish or battle." As was the case with Reitz, van Warmelo and his comrades "had more Lee-Metfords than Mausers in our possession."27 Even Boer General Christiaan de Wet recalled coming upon an abandoned British camp where he and his men "were very careful to recover every cartridge, since it was clear that the war must still continue for a long space of time." 28 Clearly the British commanders were aware that the Boers took as much clothing, equipment, and munitions as they could carry when they captured supply trains and their guards. ${ }^{29}$ Whether or not they realized that it was their own wastefulness that aided the Boers is unlikely; Reitz, at least, doubted "if the British ever realized to what an extent the Boers were dependent upon this source of replenishment." 30

Although the destruction of the farms and removal of the families did not deprive the commandos of such a percentage of food as to compel them to surrender - which they acquired as best they could by living off the land and taking from the British - it did affect the intelligence gathering ability of the Boers. ${ }^{31}$ This too, however, was only true to a degree, for the British were distrustful of burghers living out on the vast expanses of the veldt, regardless of their allegiances and therefore told them little. In the cases where Boer commandos encountered burghers they did not know, they could not always be

Commandos in General Jan C. Smuts command were so heavily clad in British khaki that Smuts had to protest the shooting of his captured men as spies. W.K. Hancock, editor, Selections from the Smuts Papers, seven volumes. (Cambridge, England: Cambridge University Press, 19661973), 1: 437.

Deneys Reitz, Commando: A Boer Journal of the Boer War. (London: Faber and Faber, 1929), 187. Reitz makes numerous references to acquiring new clothing, horses, and equipment through either carelessness by the British or through capture. In one instance he acquired a horse that belonged to Winston Churchill's cousin, a Lieutenant named Sheridan, who had been killed during a Boer attack, 230 and 231.

Dietlof van Warmelo, On Commando. (Johannesburg: A.D. Donker Publishers, 1977), 74. Christiaan De Wet, Three Years War. (New York: Charles Scribner's Sons, 1903), 193.

According to General Jan Smuts, Boer commandos frequently came out of battles with more ammunition than when they entered. Franzjohn Pretorius, Life on Commando During the AngloBoer War, 1899-1902, Marcelle Manley, translator. (Cape Town, Pretoria, and Johannesburg: Human and Rousseau, 2000), 95.

31 Reitz recalled eating ostrich eggs and killing what he termed "savage" cattle, thus barring the British's ability to systematically kill all edible creatures on the veldt those sources were available, if not always bountiful. Reitz, Commando, 262. 
certain of their loyalty either, even if they were Boers. Thus, despite the useful assistance given in certain instances, complete trust was impossible. As with so much of their equipment, enterprising Boer commandos gathered intelligence from their enemies, who could not readily distinguish loyal Boers from those fighting them. Although the British high command was rightly cautious of the civilian population, average British troops not only proved wasteful, but also talkative. On one occasion two lost commandos looking to find General Smuts came upon a British sergeant and struck up a conversation about the famed Boer general. In the process the sergeant informed the inquisitive travelers that he had been captured by Smuts' forces the previous day and guessed they were only an hour or so up the road. As a result of that revelation, "we were so delighted with this unexpected good news that we insisted upon shaking hands with our informant, who could not at first understand our elation." 32

The greatest military effect caused by the concentration camp policy was not drastically depriving the Boers of supplies, intelligence, or comfort; in fact the greatest result was a hardening of Boer resolve. There were two reasons for this reaction, the first obviously grew out of the anger and determination to seek justice against those who had so cruelly mistreated their families and destroyed their farms. Secondly, by gathering the Boer families in camps and providing them with sustenance, meager as it was at times, the commandos were unburdened of the responsibility of looking after their families.

For the commandos, the fact that they now had nothing to tie them down (but they knew their families were gathered at various places, and theoretically being taken care of) was less important emotionally than their virulent animosity toward the British for instituting the policy in the first place. While on his most celebrated raid into the Cape Colony, begun in June 1901, Jan Smuts was sickened by the destruction wrought by the British:

Dams everywhere full of rotting animals; water undrinkable. Veld covered with slaughtered herds of sheep and goats, cattle and horses. The horror passes description

.... Surely such outrages on man and nature must move to a certain doom. . . The moral debasement which can inflict such horrible sufferings on innocent brutes [Smuts was referring to the slaughtered farm animals] must be something appalling. ${ }^{33}$

Rather than render Smuts and his men unable or unwilling to continue, they fought on for almost another year, and were prepared to continue were it not for the political leaders convincing them and the other "bitter-enders" to agree to the peace settlement.

The anger of Smuts' fellow "bitter-ender", Christiaan De Wet, fueled his determination to vigorously carry on. De Wet recalled with rage how, first Roberts and then, Kitchener had ordered the full-scale destruction of the Boer way of life: "Everywhere houses were burnt down or destroyed with dynamite. And, worse still, the furniture itself and the grain were burnt, and the sheep, cattle and horses carried off. Nor was it long before horses were shot down in heaps, and the sheep killed by the

\begin{tabular}{ll}
\hline 32 & Reitz, Commando, 275. \\
33 & Hancock, Smuts Paper, 1: 408.
\end{tabular}


thousands," and as for the families, they were "carried away to the concentration camps, which the British called refugee Camps (Camps of Refuge). How incorrect, indeed!" ${ }^{34}$ As the South African Conciliation Committee pointed out in one of its many pamphlets, "It is a historical fact that the severities inflicted upon our colonists by Lord Cornwallis during our struggle with the American colonies only brought recruits to Washington and made the colonists irreconcilable." ${ }^{35}$ Kitchener had miscalculated terribly. Instead of breaking the will of the Boer commandos he had provoked them to fight on, with renewed desperation and anger.

According to military logic Kitchener chose the correct path, one certain to wreck havoc on his enemy, which would lead that enemy to collapse under the mounting pressure caused by the destruction of his way of life and danger to his family. The key to military logic, however, is knowing when to follow its dictums and went to abandon them. Failing to see that the concentration camp policy was not achieving his goals, Kitchener (and Roberts before him), "made himself a recruiting agent for reviving the commandos. Both, de la Rey and the new breed of zealous officers whom they were raising made good use of the ruined and embittered men who came to them from burnt homes." ${ }^{36}$ They had, in fact, prolonged the war. ${ }^{37}$

The concentration camps were more than a military disappointment, which Kitchener admitted when he gladly turned control of the first camps (begun in November 1900) over to the civil authorities under Lord Milner. By that time Kitchener not only had to face the fact that the policy was a military failure, but it had also become a sociopolical fiasco. To be sure, the initial decision by Lord Roberts on 16 June 1900 was based, in part, in a humanitarian desire to help the suffering civilians whose farms had been destroyed. The irony, of course, is that had it not been for Roberts' order to burn certain Boer farms there would not have been a need for any humanitarian assistance. ${ }^{38}$

Some British officials, including Kitchener demurred on the subject of why the camps were started. Both Roberts and Kitchener claimed that given the necessities of war that resulted in the burning of Boer farms, it was inhumane to leave the families homeless and without food on the veldt. However, as S. B. Spies has noted, "for some months the families rendered homeless by the policy of devastation had indeed simply

$34 \quad$ De Wet, Three Years War, 192.

35 Published in early November 1900, this was the fifty-eighth pamphlet published by the South African Conciliation Committee (one of many anti war organization in Britain). Stephen Koss, editor, The Anatomy of an Antiwar Movement: The Pro-Boers. (Chicago and London: The University of Chicago Press, 1973), 172-173.

W.K. Hancock, Smuts: The Sanguine Years, 1879-1919, two volumes. (Cambridge, England: Cambridge University Press, 1962), 1: 124.

37 Embittered Boer women, who bore the brunt of the scorched earth and concentration camp policies, also played a role in motivating their armed male burgher relatives to fight on. Nasson, South African War, 219.

Roberts' order to burn the farms and imprison the civilians was in response to the frequent attacks on the rail lines which he had been unable to stop, or even slow. In the Times' history of the war Amery suggests that the order, as well as two others that followed over the course of two months, were based on what the Germans did in 1871 during the Franco-Prussian War. Amery, Times History of the War, 4: 492. 
been left on the veld." ${ }^{39}$ So much for Roberts' and Kitchener's humanitarian concerns. Despite this and other slight of hand tricks to obscure the true nature and responsibility for the policy it is clear that "the concentration camps were, in fact, established for military reasons." ${ }^{40}$

Roberts' goal was to stop the attacks on the rail lines and not the wonton destruction of Boer farms and the uprooting and imprisonment of innocent Boer civilians. By November the troops in the field had lost sight of their commanders' intentions, so Roberts issued a clarification of his original orders. In the memorandum issued on 18 November Roberts stated:

No farm is to be burnt except for an act of treachery, or when troops have been fired on from the premises, or as punishment for breaking of railway or telegraph line, or when they have been used as bases of operations for raids, and then only with the direct consent of the general officer commanding, which is to be given in writing; the mere fact of a burgher being absent on commando is on no account to be used as a reason for burning the house. All cattle, wagons, and foodstuffs are to be removed from all farms; if that is found to be impossible, they are to be destroyed, whether the owner be present or not. ${ }^{41}$

Even though Roberts made it very clear that farm burning while he was in charge was only acceptable if the farms were used for military operations against either the railways or his troops, there was an outcry in England. His November memorandum was designed not only to clarify the situation for the soldiers, but also to appease the growing political unrest in England. ${ }^{42}$ The pressure he received from above was the first indication that a small, but persistent antiwar group, erroneously called the "pro Boers," might pose a problem for the military. ${ }^{43}$ It is doubtful whether or not Roberts' effort to stifle any controversy before it grew would have worked, but the point is moot because Roberts returned to England less than two months later - having done nothing to sate the growing public unrest. ${ }^{44}$

S.B. Spies, Methods of Barbarism? Roberts and Kitchener and Civilians in the Boer Republics Jamuary 1900-May 1902. (Cape Town and Pretoria: Human and Rousseau, 1977), 185.

Spies, Methods of Barbarism, 188. Spies, who has done some of, if not, the most extensive work on the concentration camp policy, takes up the range of British explanations and justification for the policy throughout his study, and systematically refutes them. Amery, Times History of the War, 4: 493, italics mine.

Ibid.

43 The name "Pro Boers" gave a generally inaccurate view of those who simply opposed the war. Including in the outspoken group were not only politicians and many average citizens, but also Arthur Conan Doyle's mother and Irish actress Maud Gonne. The Irish, of course, opposed the British as much as they opposed the war. S.B. Spies, "Women and the War," in The South African War: The Anglo-Boer War 1899-1902, Peter Warwick, general editor. (Harlow, England: Longman, 1980), 181.

As the severity of the concentration camp policy became more widely known, it actually strengthened the "Pro Boer" element, which had suffered terrible losses during the "khaki elections" the previous year. According to historian Bernard Porter, "If they were to be tarred with that brush anyway (being called Pro Boer), they might as well deserve it." Bernard Porter, "The Pro Boers in Britain," in Warwick, editor, The South African War, 250. 
There was an important distinction between Roberts' insistence on not displacing Boer families or destroying their farms and what Kitchener implemented. Kitchener did not see the burning of farms and interning of Boer families as a means simply to deal with attacks on the railways. On 21 December Kitchener, by then Commander in Chief, made it clear that he intended to expand Roberts' original policy into a the cornerstone of his strategy to combat the Boer commandos. According to the plan:

The General Commanding-in-Chief is desirous that all possible means shall be taken to stop the present guerilla warfare. Of the various measures suggested for the accomplishment of this, one which has been strongly recommended, and has lately been successfully tried on a small scale, is the removal of all men, women, and children and natives from the Districts which the enemy's bands persistently occupy. This has been pointed out . . . as the most effective method of limiting the endurance of the Guerillas, as men and women left on the farms, if disloyal, willing supply Burghers; if loyal, dare not refuse to do so.",45

Issuing orders and being prepared to carry them out are too frequently different issues, as Kitchener learned over the next seventeen months.

If Roberts' original policy initiated anger in certain circles back in England, Kitchener's use of concentration camps as a strategical weapon unleashed a whirling dervish of criticism. There was one whirling dervish in particular that became a source of extreme annoyance. Once the burning of farms and interning of civilians became common knowledge in England, humanitarian groups began to focus their attention on the displacement of Boer women and children. One such group, the South African Women and Children's Distress Fund, sent a three-woman delegation to investigate the conditions at the "refuge camps." The most important member of that delegation was Emily Hobhouse, or as Kitchener came to call her, "that bloody woman."46

Although Kitchener did not know it at the time, when Emily Hobhouse set sail for Cape Town on 7 December 1900, his lack of understanding, preparation, and for the most part, concern for the Boers in the camps was about to become the cause of a great deal of trouble he did not need. ${ }^{47}$ The military's inability to foresee just how monumental a task it would be to hold over one hundred thousand Boer civilians resulted in deadly living conditions. The suffering encountered by Hobhouse was unimaginable. After her second day she reported to the Fund,

this camp system is a wholesale cruelty. It can never be wiped out of the memories of the people. It presses hardest on the children. They droop in the terrible heat, and with the insufficient, unsuitable food; whatever you do, whatever the authorities do, and they are, I believe, doing their best with very limited means, it is all only a miserable patch upon a great ill.",48

\footnotetext{
$45 \quad$ Kitchener proclamation cited in A.C. Martin, The Concentration Camps 1900-1902. (Cape Town, South Africa: Howard Timmins, 1958), 7.

46. Mangus, Kitchener, 180.

$47 \quad$ Farwell, Anglo-Boer War, 401.

48 Hobhouse cited in Koss, Pro Boers, 198.
} 
Hobhouse, too, could never wipe out the memories of what she saw during her inspection tour. Among the deaths she witnessed while touring the camps, she described one in a letter:

I was called to see a sick baby. The mother sat on her little trunk, with the child across her knee. She had nothing to give it and the child was sinking fast .... There was nothing to be done and we watched the child draw its last breath in reverent silence . . . . Dry-eyed but deathly white she [the mother] sat there motionless looking not at the child but far far away into the depths of grief beyond all tears ... The scene made an indelible impression upon me. ${ }^{49}$

Her tour was a brief one, in part because the officials had finally realized she was making trouble for them, and partly because she believed she could make a greater difference in England, where her comments would not be censored. ${ }^{50}$ So she sailed home in late May 1901. Once there, she embarked on a personal crusade. Slowly her efforts and connections forced the British political leaders in London to consider the accuracy of her charges and viability of her demands.

What Hobhouse described was incredible. Overcrowding was the norm; "In some camps two, and even three, sets of people occupy one tent, and 10 , and even 12 , persons are frequently herded together in tents of which the cubic capacity is about 500 c.f.",51 Most internees were housed in tents, but a few did live in large metal shelters that were subdivided into "apartments". Refusing to describe these latter structures as houses, Hobhouse referred to them as "rows of corrugated iron," which did not have floor to ceiling partitions between apartments. This, she noted, resulted in "draught and infection [able to] play through the entire structure." Regardless of whether or not they were living in tents or huts, only a few had beds or mattresses. As a result, most of the inhabitants slept on the damp ground, which was made much worse during rainstorms. ${ }^{52}$ Hobhouse admitted that it was "so strange to think that every tent contains a family and every family is in trouble: loss behind, poverty in front, sickness, privation and death in the present." 53

The insufficient and crowded housing was only part of the problem. Living in such unsatisfactory shelters exposed the internees to extreme heat during part of the year and then cold and wind during the winter months. Adding to the limited protection against the winter weather was the scarcity of fuel. One camp commander plaintively reported, "The scarcity of wood has been the cause of considerable anxiety, and is one of the greatest hardships among the people." 54 As Hobhouse noted, the insufficient fuel

\footnotetext{
49 Hobhouse cited in Jackson, Boer War, 158.

$50 \quad$ During her tour she wrote her brother, "since I have been thus made public they began censoring my letters which is most annoying." Emily Hobhouse to Leonard Hobhouse, February 25, 1901, cited in Jennifer Hobhouse Balme, To Love One's Enemies. (Cobble Hill, British Columbia: Hobhouse Trust, 1994), 126.

$51 \quad$ Hobhouse's report on her findings in Balme, To Love One's Enemies, 211.

$52 \quad$ Balme, To Love One's Enemies, 212.

53 Balme, To Love One's Enemies, 131.

$54 \quad$ Balme, To Love One's Enemies, 184.
} 
supply made baking "almost impossible, and often the meat cannot be cooked."55 The food supplied, whether cooked or not, was insufficient and all too frequently of the lowest quality. There were no vegetables, "the meat (as often) is moggoty and the coffee coppery and undrinkable." This was the situation Hobhouse found during her brief inspection tour.

Given the denials thrown up by officials in South Africa, that the government was naturally skeptical of the degree of severity of the situation is not surprising. In fact, there were a number of officials who dismissed the notion that the camps were anything but well-run facilities. General John Maxwell, who was military governor of Pretoria, wrote that the camps were "going well, the inmates are well cared for, and though the death rate amongst the children is excessive, it is in most cases the fault of the mothers themselves. ${ }^{" 56}$ After speaking with one of the other British officials, General Pretyman, Hobhouse became well aware that "Their [British officials] way out of it is to abuse the Dutch as a whole, and these mothers in particular, as brutal, heartless, ignorant people who deliberately murder their children."57 This placing the blame on the Boers themselves was one of the two most common defenses given by British officials. The other was to suggest that they would have died regardless of their internment. This was the thinking of one of the camp doctors who wrote, "It is my firm belief that if the camps had not been established, sickness and mortality would have been far greater on the farms and villages." 58 This was true, of course, since Kitchener's men had burned the farms, killed the livestock, destroyed their crops, and left them with nothing. Lord Milner, was less convinced. He noted, "it does not seem to me altogether a complete answer to say that the aggregation of people who are specially liable to infections disease had produced a state of things which is inevitable." 59

While the British officials in South Africa spent too much time making excuses, the real causes of the high mortality rate continued to kill at an alarming pace (at its peak some 3,156 persons, mostly children, died in October 1901 out of a total population of 113,506 in all the camps). ${ }^{60}$ Epidemics spread rapidly in the closely confined camps, where the weak succumbed to measles, influenza, enteric fever, as well as pneumonia, dysentery, and bronchitis by the thousands. Without improvements the internees remained weak and susceptible to all such killers. For all of her work, and the outrage of pro Boer MPs like David Lloyd George, nothing was done.

Finally a somewhat befuddled government acted by appointing an "impartial" committee to look into the allegations. The decision to do so was in response to the growing outcry over reports made by Hobhouse and rumors of the atrocities. Even down in his post in South Africa, Lord Milner summed up what was important about the public grumblings, noting, "The mortality in the concentration camps has undoubtedly roused

\footnotetext{
55 This and the following quotation are taken from the Hobhouse report in Balme, To Love One's Enemies, 211-212.

$56 \quad$ Maxwell, cited in Farwell, Anglo-Boer War, 407.

$57 \quad$ Hobhouse journal entry for March 15, 1901, cited in Balme, To Love One's Enemy, 149.

58 Dr. Kay quoted in Farwell, Anglo-Boer War, 407.

59 Headlam, Milner Papers, 2: 228-229.

60 Martin, Concentration Camps, 31.
} 
deep feeling among people who cannot be classed as pro-Boers." ${ }^{\text {"61 }}$ This was a key point of concern; the public, and not just the pro Boers, was worried that what they heard might be true. The committee finally created to look into the allegations made public by Hobhouse and her colleagues was officially named the Fawcett Committee, but was generally referred to as the Ladies Committee. It was made up of six women, all either doctors or nurses, and was sent to South Africa in July. Hobhouse, having been dismissed by the government as biased, was not among them. In three months of examining the camps, the Ladies Committee took samples of the available water, looked at the amount of food supplied, shelter provided, medical attention available, and other points of concern. By the time their recommendations were presented to Parliament most of the camps had been transferred from military to civilian control, meaning Kitchener was relieved of a task for which he was ill suited.

What the Ladies Committee learned in their three months had by then become painfully aware to Lord Milner when the civil authorities began taking over the camps: "We are suddenly confronted with a problem not of our making, with which it was beyond our power properly to grapple." Milner instituted as many of the suggested changes as was possible, but he faced an uphill struggle; the task was a monumental one. He admitted, "A great deal depends upon the Superintendents and other officers of the camps, and upon the character of doctors, matrons and nurses." Unfortunately he had to admit being "terribly short in all these respects." 63

To Milner's credit, he pressed on. The Ladies Committee, likewise, deserved a great deal of admiration, not so much for the originality of their suggestion, for many of their proposals were the same ones made by Emily Hobhouse, but for their ability to work within the British system - something Hobhouse was unable to do. Hobhouse, most of all, deserved the credit for bringing the issue to the forefront in England and thus forcing the British government to look into the camps. Despite all of their efforts, one camp doctor dismissed Hobhouse and her companions who toured the camps with her as "a few hysterical unsexed women who are prepared to sacrifice everything for notoriety." The doctor did not appreciate the activities of "sexless busybodies with nothing better to do than decry everything and everybody." 64

The changes that began to take place once the camps were in Milner's hands and after the Ladies Committee had filed its report came too late for thousands of Boers, as well as an almost equal number of natives. For Kitchener, the military, and the government attempting to win a war, the policy had been a major mistake. The public outcry over the camps was a source of hope for Boer commandos, who were aware that the "fearful state of things has undoubtedly touched the conscience of the English Public, as the papers are full of bitter complaints from influential supporters of the Salisbury Policy. Perhaps God's will is that through our ill-treated women and children a decisive end should be made of this war." 65 Smuts' hopes for something good to come out of the

\footnotetext{
$61 \quad$ Headlam, Milner Papers, 2: 228.

62 Headlam, Milner Papers, 2: 229

63 Headlam, Milner Papers, 230.

64 Dr. Kay, quoted in Farwell, Anglo-Boer War, 410.

65 Smuts quoted in Hancock, Smuts, 1: 142.
} 
deaths of perhaps as many as 25,000 Boer civilians were dashed when he was finally convinced in May 1902 that peace was the only choice. ${ }^{66}$

The Boer War proved to be nothing short of a nightmare for the British government. It went on too long, was too expensive, and cost too many lives. It was marked by a number of blunders and mistakes. Historically speaking, the deadliest of those mistakes was the decision to intern Boer civilians as a means to bring about a speedier end to the war. Unfortunately for the over one hundred thousand Boer, as well as a nearly equal number of native

African, internees, and several additional thousand British soldiers and Boer commandos who died during the prolonged war, the concentration camp policy was a flawed strategy. Every aspect of the policy was flawed. Clearly, Lord Kitchener not only misjudged the situation, but more importantly he misunderstood his enemy. Rather than being forced to surrender, Boer commandos became embittered by the idea of the destruction of their farms and the interment of their families. Just as important as strengthening Boer resolve, the British failed to conceive of the magnitude of such an undertaking. This shortsightedness led to the deaths of tens of thousands of the internees and created a political storm for the government. The last of Queen Victoria's colonial wars was a debacle, and the concentration camp policy was the tragic nucleus of that disaster.

Of course, Smuts did not count the 14,000 or so black Africans who died in the more than seventy separate camps that housed over 115,000 persons by the end of the war. B.E. Mongalo and Kobus du Pisani, "Victims of a white man's war: Blacks in concentration camps during the South African War (1899-1902), 149 and 181. See also, Peter Warwick, "Black People and the War," in Warwick, general editor, The South African War, 204-205. Warwick makes it clear that Boer camps, even those for the families of the bitter-enders, were far better than those for black Africans. 